\title{
Epidemiology of Multiple Sclerosis: A Critical Overview
}

\author{
A.D. Sadovnick and G.C. Ebers
}

\begin{abstract}
The decisive conclusions to be drawn from the available epidemiological data, mostly geography and prevalence, of MS are: (1) a north-south (as well as west-east in the United States) gradient exists independent of genetic/racial factors; (2) major differences in prevalence occur in the absence of latitude differences; (3) individuals from the same ethnic derivation have either similar prevalence rates or very different prevalence rates in widely separated geographical areas and (4) specific resistant isolates are shown to exist regardless of latitude. Existing information leads to the almost inescapable conclusion that the epidemiology of MS cannot be explained by any single known environmental or genetic factor(s) in isolation. A combination of a heterogeneous distribution of both genetic and environmental factors appears to be required to explain the available data on MS.
\end{abstract}

RÉSUMÉ: Épidémiologie de la sclérose en plaques: une revue critique. Les conclusions formelles que l'on peut tirer des données épidemiologiques disponibles qui concernent surtout la géographie et la prévalence de la sclérose en plaques (SEP) sont: 1) il existe un gradient nord-sud (ainsi que ouest-est aux Etats-Unis) indépendant de facteurs génétiques/raciaux; 2) on observe des différences majeures dans la prévalence pour des latitudes identiques; 3 ) les individus de même origine ethnique ont des taux de prévalence similaires ou tres différents lorsqu'ils résident dans des régions très éloignées les unes des autres; 4) des isolats spécifiques résistants, sans égard à la latitude, one été démontrés. Des données actuelles, on ne peut que conclure que l'epidémiologie de la SEP ne peut être expliquée par un seul ou des facteur(s) environnemental(aux) ou génétique(s) isolé(s). Une combinaison d'une distribution hétérogène de facteurs, tant génétiques qu'environnementaux, semble être nécessaire pour expliquer les données actuelles sur la SEP.

Can. J. Neurol. Sci. 1993: 20: 17-29

The non-random geographic distribution of multiple sclerosis (MS) has provided considerable allure for epidemiologic study since the patterns are believed to reflect underlying causes.' Such studies have traditionally focussed on the geographic distribution (comparing prevalence data) or on case-control studies, which seek to establish correlations with putative causal environmental factors. There are few, if any, diseases of unknown cause with such detailed information available about worldwide prevalence and incidence. Despite this wealth of data, the results of epidemiological studies have often led to ambiguous interpretation rather than to definitive correlations supporting specific environmental hypotheses. In general, there has been more consensus for demographic and clinical features than for concepts of pathogenesis and for treatment.

Charcot $^{2}$ was the first to comment on the geographic distribution of MS by noting that while prevalent in France, the disease was not well-recognized in Germany or England. Subsequent study has shown both these countries now actually surpass France in prevalence and incidence and perhaps always have done so. This epitomizes the importance of a disciplined and uniform epidemiologic approach in studies of disease prevalence.

Key factors for successful epidemiological studies include accurate diagnosis and unbiased case ascertainment, both of which pose special problems in MS. Certain diagnosis (and exclusion of diagnosis) of MS is not always possible in the living patient, even with modern advances in laboratory diagnosis. ${ }^{3}$ An obstacle in identifying cases and controls for epidemiological studies is the acknowledged lagtime from the clinical onset of MS to diagnosis, which now averages some four years. Complete case ascertainment in a defined geographic region lessens the chance that observations result from subtle or unrecognized selection bias. Repeat surveys routinely appear to increase prevalence figures. Comparison of prevalence rates is not without hazard since methodology is rarely identical.

In an attempt to explain the geographic distribution of MS, considerable effort has been focussed on traditional environmental factors. There have been numerous supporters for a

From the Multiple Sclerosis Clinic, University Hospital-UBC Site (A.D.S.) and Department of Medical Genetics (A.D.S.), University of British Columbia, Vancouver, and the Multiple Sclerosis Clinic, University Hospital (G.C.E.) and the Department of Clinical Neurological Sciences (G.C.E.). University of Western Ontario, London

Received February 11. 1992. Accepted in final form August 27, 1992

Reprint requests to: Dr. A.D. Sadovnick, Department of Medical Genetics, University of British Columbia, \#226-6174 University Blvd., Vancouver. British Columbia, Canada V6T 123 
purely environmental causation of MS and the attractiveness of this notion derives from the promise that a relatively simple act of omission (or commission) could serve to prevent the disease. The intensive study of MS prevalence in the 1950's and 1960's coincided with research on paralytic poliomyelitis which culminated in the elucidation of the cause and the subsequent development of an effective vaccine. Not surprisingly, parallels were sought between the epidemiology of the two diseases. Prevailing concepts of the geographic distribution, age specificity of a putative precipitating infection and socioeconomic predilection in MS have owed some of their vitality to analogizing with poliomyelitis. ${ }^{4}$

Contemporaneously, the notion of a common viral infection of long latency in which only a relatively small proportion of those affected by the virus actually develop the disease in question became popularized. A critical age for susceptibility was suggested by migration studies and the identification of "slow viruses" provided both precedent and analogy to support the long latency concept (see below). Extrapolating to the observed north-south gradient in the Northern Hemisphere for MS, it was suggested that children in those parts of the world (regions nearer the equator) with poorer sanitation would be exposed to the "virus" at an earlier age compared with those living in more temperate and developed areas. Younger children could thus develop immunity by the time they reached the critical age for disease susceptibility. Similarly, this hypothesis could explain some, but not all, of the racial differences in MS within a defined geographic area. It cannot be excluded that genes resulting from racial admixture may, to some degree, be responsible for the development of MS. For example, the disease is relatively common in American Blacks compared to African Blacks who have less Caucasian ancestry. 5.6

Evidence against the age/social stratum-specific latent virus theory has come from Australia where there is a two-fold difference in the prevalence of MS between Perth and Hobart, but sanitary arrangements are comparable ${ }^{7}$ and Israel where differences in prevalence could not be explained by sanitation. ${ }^{8}$

The influential studies of migration to South Africa ${ }^{9}$ and Israe ${ }^{10.11}$ again implicated some crucial childhood event related to the later development of MS. The demonstration that a number of infections of the central nervous system could be followed by a long delayed expression of symptoms and signs (e.g. subacute sclerosing panencephalitis, Kuru) refocussed attention on events of early life. However, the mechanism by which observed epidemiological facts were explained by inferences drawn from these possible analogies has been neither crystallized nor well-defined.

\section{Prevalence and Incidence of Multiple Sclerosis}

\section{Overview}

In general, accurate incidence rates for MS are difficult to obtain, especially because of uncertainty about the date of disease onset (initial symptoms are often subtle and only recog. nized in retrospect) and lagtime. In addition, diagnostic uncertainty in early stages is also a factor, as incidence data depend on relatively early cases. For these reasons, the majority of epidemiological studies on MS have either made deductions about incidence from prevalence and/or mortality data or have been limited to prevalence data alone. Kurtzke ${ }^{12}$ classified MS preva- lence rates into "high", "medium" and "low" risk groups. Rates from 30 per 100,000 population characterize "high risk" areas such as northern Europe, northern United States, Canada, southern Australia and New Zealand. "Medium risk" regions (prevalence between 5 and 25 per 100,000 population) may include southern Europe, southern United States and northern Australia. "Low risk" areas (prevalence less than 5 per 100,000 population) include Asia and perhaps parts of South America. However, even within a general geographic region, there can be considerable variation. ${ }^{13}$ The marked difference in prevalence between Sicily and Malta serves as an outstanding example of this variation for two areas in close proximity (see Figure 1). ${ }^{14.15}$ Such variation may be explained by environmental factors, genetic factors or a combination of the two.

Prevalence is easier to calculate than incidence since all cases are included, regardless of disease duration. However, accurate assessment of prevalence is still difficult with a major problem being that prevalence data must rely on diagnostic accuracy which, over several decades, has nol remained constant. Accurate prevalence rates also depend on the completeness of case ascertainment. It is recognized that the smaller the community being surveyed, the more complete the case-finding. In addition, comparison of prevalence rates between areas must include an assessment of differences in disease diagnosis and case management over the study period. For example, in a less developed area or one with less accessible medical care, diagno-

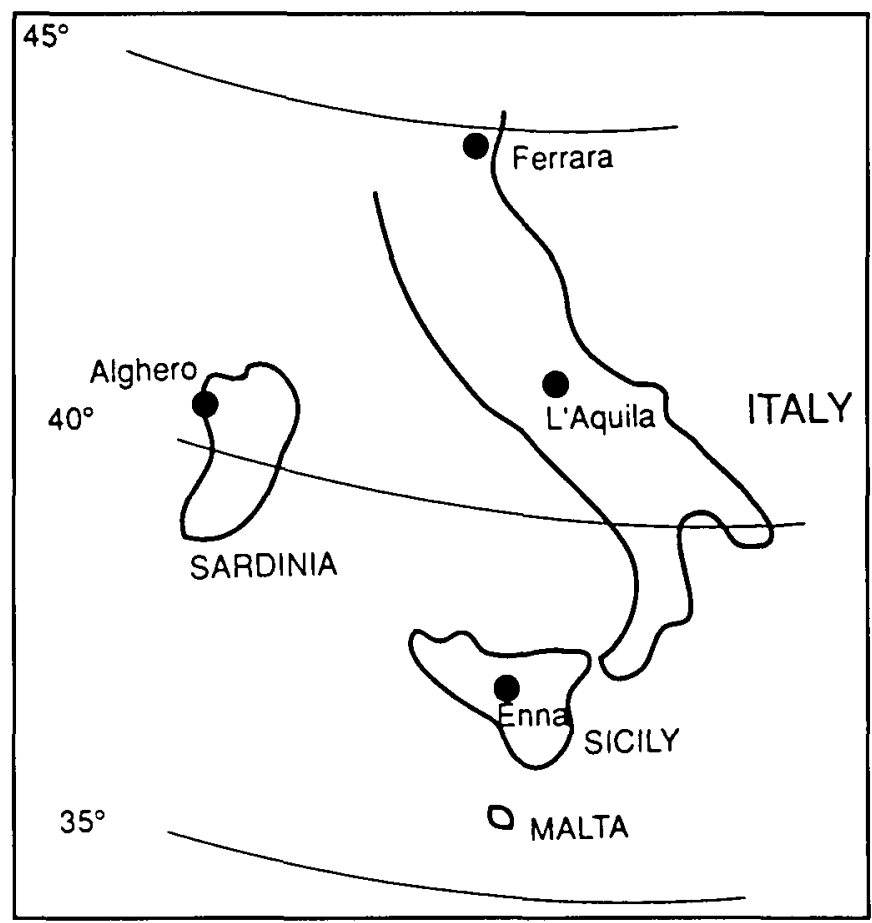

Figure 1: Comparison of Prevalence Rates for Italy. Sardinia and Sicily.

$\begin{array}{lc} & \text { Prevalence per } 10^{5} \\ \text { Alghero. Sardinia } & 50.0 \\ \text { Enna. Sicily } & 53.3 \\ \text { Malta } & 4.2 \\ \text { L'Aquila, Italy } & 33.2 \\ \text { Ferrara, lialy } & 46.1\end{array}$

Reference Rosati et al..$^{159}$ Dean et al. ${ }^{1.5}$ Vassallo et al."4 Salemi et al..$^{(0)}$ Granieri et al. ${ }^{\text {thl }}$ 
sis may be less certain and survival diminished. However, this may in reality be an artifact of less frequent diagnosis of earlier and benign cases on one hand and diminished survival among more severe cases on the other. Even within North America, comparisons between Canada and the United States are influenced by differences in health care systems. Since Canadians have essentially equal financial access to diagnostic procedures and medical care, the MS population attending Canadian medical centres may potentially be more representative of the overall MS population for disability distribution (benign/mild to severe) and also for ethnicity and socioeconomic distribution. Given the relative homogeneity of Canadian health care, prevalence comparisons within this country may have more than average validity. Finally, major changes in birth rates over the time period evaluated can influence crude prevalence rates, thus emphasizing the value of age-specific prevalence rates.

Therefore, in reviewing the massive literature on MS prevalence, it is critical to assess the methodology of each study and to only compare data from different regions after carefully determining whether such comparisons are valid. This point and its application are clearly demonstrated in the analyses of prevalence by Kurtzke, who has very well summarized this large body of literature. ${ }^{12.16}$

As early as the 1920's, it was recognized that the distribution of MS was not uniform across geographic regions. ${ }^{17-20}$ In general, all types of epidemiological surveys (prevalence, incidence, mortality) find that in temperate climates, many economicallydeveloped occidental countries tend to have a higher rate of MS. In the Northern Hemisphere, a diminishing north-south gradient for MS prevalence has been well-described. ${ }^{21.22}$ The reverse, a south-north gradient, has been reported in the Southern Hemisphere. ${ }^{22,23}$

\section{Lessons from Animal Models of Autoimmune Disease}

It is beyond the scope of this review to discuss the genetics of spontaneous autoimmune disease in mice. However, all models studied show polygenic inheritance of susceptibility and some demonstrate fascinating epidemiologic lessons. The best understood of these models is the non-obese diabetic inbred mouse (NOD) which, when shipped in colonies around the world, showed a markedly variable penetrance of diabetes, despite documented purity of breeding stocks and genetic homogeneity. ${ }^{24}$ Despite the presence of the appropriate background of genetic susceptibility, the penetrance proved to be very strongly influenced by early life diet, cleanliness of environment and viral contamination of breeding colonies. A germ-free environment in early life resulted in full penetrance of diabetes. It is too early to know if these observations are relevant to the epidemiology of MS but they serve to emphasize several relatively unexplored avenues in MS and to provide a fascinating example of the interaction of genes and early life microenvironment. (For more in depth discussion of lessons from animal models, see reference 25 .)

\section{Temporal Changes}

The epidemiological literature contains numerous examples of changes in incidence and prevalence for specific disorders over time. However, these follow-up studies must be critically assessed to determine whether observed changes are real or reflect changes in medical practice, environment or other factors. In MS, it is generally recognized that more recent surveys and repeat surveys frequently find higher prevalence rates (see Table 1). The literature contains numerous such examples but the reverse has also been reported (e.g. Winnipeg. Manitoba and Western Poland).

Several Canadian prevalence studies have been conducted. ${ }^{26-34}$ Re-evaluation of the same population was first done in Winnipeg, Manitoba, the site of the earliest prevalence study in the country. The initial survey, based on data from patient records and death certificates for the years 1939 to 1948, found a prevalence rate of 39.6 per 100,000 population. A follow-up study in $1961^{28}$ diagnostically re-evaluated 144 of the initial study group. ${ }^{27}$ Diagnoses remained consistent for $71.5 \%$ of cases. ${ }^{28}$ Of the 109 patients diagnosed as "probable MS" in the first study, re-evaluation confirmed this diagnosis in 85 cases $(78.0 \%)$. Of the remaining 24 cases, seven $(6.4 \%)$ were reclassified as "possible MS" and the rest were diagnosed as either "unlikely MS" (14/109; 12.8\%) or "not MS" $(3 / 109 ; 2.8 \%)$. In part because of more rigid diagnoses. the prevalence rate in the follow-up study ${ }^{28}$ decreased to 35.4 per 100,000 population see Table 1 . In Western Poland, a resurvey similarly found a lower prevalence rate in the more recent study ${ }^{35.36}$ (see Table 1), but a possible explanation was that the findings may reflect an increase in population figures due to a higher birth rate rather than a true fall in MS frequency.

Published prevalence rates in Canada have increased in more recent surveys. This was most dramatically noted in the study from Saskatoon, Saskatchewan which reported a prevalence rate of 134 per 100,000 population. ${ }^{32}$ Initial reaction was that research should focus on Saskatoon to determine why the prevalence was so high. However, it soon became clear that this rate was probably more related to the timing of the survey rather than specific risk factors for MS being higher in Saskatoon. Al the time of publication, the Saskatoon study was the only one in recent years designed to specifically determine prevalence. Furthermore, improved survival, the availability of various diagnostic tests to assist in the diagnosis of $\mathrm{MS},{ }^{3}$ especially in early and benign cases, and the institution of the universal coverage medical insurance program in Canada all contributed to the apparent rise in prevalence. Subsequent studies, including both coasts of Canada and the province of Ontario ${ }^{26,29,34}$ also reported comparable prevalence rates (see Figure 2), with the notable exception of Newfoundland where the prevalence was only halt that reported in the other Canadian centres.

Incidence and prevalence rates for MS have been repeatedly reassessed for Rochester and Olmsted County, Minnesota, largely because of the excellent data base at the Mayo Clinic. The reported prevalence rate in Rochester increased from approximately 46 per 100,000 in $1915^{37}$ to 108 per 100,000 in $1978^{3.4}$ and to 173 per 100,000 in $1985^{39}$ - see Table 1 . Of interest, the incidence rate for Rochester remained stable at about 3.6 per 100,000 from 1905 to $1974 .{ }^{37.38}$ However, re-evaluation of all possible MS cases for the period 1905 to $1984^{40}$ found an increased crude incidence rate of approximately 3.4 and 7.7 per 100,000 population for males and females respectively. It remains uncertain whether this increase in incidence is rcal or reflects less rigid application of diagnostic criteria and/or improved case ascertainment, study design and diagnostic capabilities. ${ }^{38}$ These figures represent the highest incidence or prevalence rates reported in North America. It will be of great interest to know if this incidence will be maintained. Similar findings 
are reported from western Norway. In Hordaland County, the incidence for definite/probable MS appears to have increased from 1.12 per 100,000 in 1953 to 1957 to 3.50 per 100,000 for 1973 to $1977 .{ }^{41}$ The incidence for 1978 to 1982 was lower than for the previous five year period, but these data must be interpreted with care because of the relatively long interval from MS onset to diagnosis. In Möre and Romsdal County, the average annual incidence increased from 1.94 per 100,000 during the period 1950 to 1954 to 3.78 per 100,000 for 1975 to 1979.42

Similar reports of increased prevalence rates over time have been reported in both the Northern and Southern Hemispheres ${ }^{7.23 .43-46}$ (see Table 1). The question of an apparent increase in MS prevalence has dashed the hopes of those who may have thought that they had heard the last of MS prevalence studies. In fact, the lack of understanding of the nature of the environmental effect demands an open mind. The implications of an increasing prevalence are too important to ignore. Although pathological confirmation of these changes in prevalence rates are elusive, data from high risk areas show that silent MS at autopsy may approach symptomatic MS in prevalence. ${ }^{47}$

\section{Migration Studies}

Migration studies, at least in theory, should be decisive in distinguishing between environmental and genetic factors. Studies of migration are much easier in concept than in execution. In principle, studies focus on migrants who move from an area of high risk to an area of low risk or vice versa. If migrants adopt the risk of their new area of residence, an environmental cause is believed to be operative. However, a number of undocumented assumptions are often made in these studies, the most

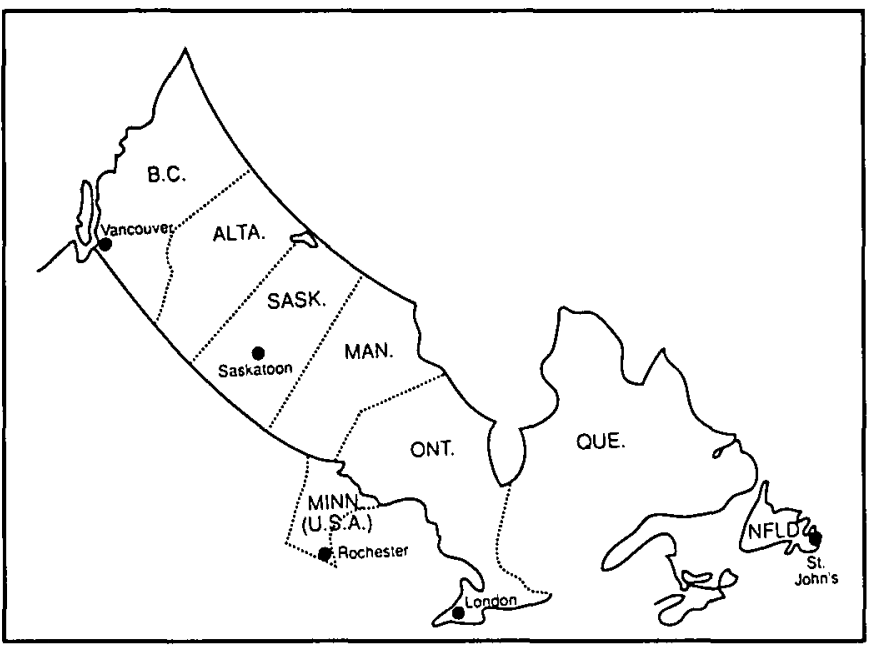

Figure 2: Comparison of Prevalence Rates across Canada and for Rochester, Minnesota.

$\begin{array}{lcl} & \begin{array}{c}\text { Prevalence } \\ \text { per } 10^{5}\end{array} & \text { Reference } \\ \text { British Columbia (1982) } & 91.0^{a} & \text { Sweeney et al. }{ }^{20} \\ \text { Saskatoon. Saskatchewan (1977) } & 110.0^{4} & \text { Hader et al. } \\ \text { London. Ontario (1984) } & 94.0^{4} & \text { Hader et al. } .^{29} \\ \text { Newfoundland (1985) } & 55.2^{a} & \text { Pryse-Phillips et al. }{ }^{34} \\ \text { Rochester, Minnesota (1985) } & 173.0^{4} & \text { Wym et al. }{ }^{39}\end{array}$

"Prevalence rates include probable MS only. Rates may thus differ from those in Tables I and 2 which may include possible cases also. important being that migrants are representative of the country from which they come. Secondly, it is assumed that these migrants, when they settle in their new homeland, distribute themselves randomly. It is doubtful if either of these assumptions is ever true. The greatest migrations in recent history have invariably been prompted by religious persecution, wars or other upheavals. As well, migrants are commonly selected for economic, social, religious, health-related and even personality and anthropologic characteristics. The most striking example in which these considerations were paid no heed may have been the study of Vietnamese migrating to France whose MS risk appeared to increase. These migrants all had a French parent which, as this affected their ability to emigrate from Viet Nam,

Table 1: Temporal Changes in the Prevalence of Multiple Sclerosis

\begin{tabular}{lccc}
\hline \hline Location & $\begin{array}{c}\text { Prevalence } \\
\text { Date or Period }\end{array}$ & $\begin{array}{c}\text { Prevalence/ } \\
\mathbf{1 0 0 , 0 0 0} \\
\text { Population }\end{array}$ & Reference \\
\hline $\begin{array}{l}\text { I. Canada } \\
\text { Winnipeg, Manitoba }\end{array}$ & $1939-1948$ & 39.6 & $\begin{array}{c}\text { Westlund \& } \\
\text { Kurland }^{27} \\
\text { Stazio et al. }{ }^{28}\end{array}$
\end{tabular}

II. Rochester, Minnesota

$\begin{array}{rrr}1915 & 46.0 & \text { Percy et al. }{ }^{37} \\ 1978 & 108.0 & \text { Kranz et al. } .^{38} \\ 1985 & 173.0 & \text { Wynn et al. }{ }^{39}\end{array}$

\section{Australia}

Perth

June 30,1961

19.6

June 30,1981

29.9

Newcastle

$$
\text { June } 30,1961
$$

19.3

Newcastle

June 30,1981

36.5

Hobart

June 30, 1961

33.0

Hobart

June 30,1981

75.6

IV. Western Norway

\section{Hordaland County}

Jan 1, 1963

20.0

Jan 1, 1983

59.8

More \&

Romsdal County

Jan 1, 1961

24.3

Jan 1,1985

75.4

McCall et al. ${ }^{7}$

Hammond

et al. ${ }^{23}$

McCall et al. ${ }^{7}$

Hammond

et al. ${ }^{23}$

McCall et al.

Hammond

et al. ${ }^{23}$

Presthus ${ }^{45}$

Larsen et al. ${ }^{41}$

Midgard

et al. ${ }^{42}$

Midgard

et al. ${ }^{42}$

V. Barbagia, Sardinia

$$
\text { Dec 31, } 1975
$$

40.7

Granieri

and Rosati,

Oct 24,1981

65.3

Granieri

et al. $^{44}$

\section{Western Poland}

\begin{tabular}{ccc} 
Jan 1, 1965 & 51.19 & $\begin{array}{c}\text { Cendrowski } \\
\text { et al. }{ }^{35}\end{array}$ \\
Dec 31, 1981 & 42.87 & $\begin{array}{c}\text { Wender } \\
\text { et al. }\end{array}$ \\
\hline
\end{tabular}


was presumably not true of those unable or unwilling to migrate. However, this obvious genetic difference was ignored since the population remaining in Viet Nam was used as the comparison group for the "expected" prevalence of MS among Vietnamese migrants to France. ${ }^{48}$

The frequency of MS differs among populations of the same ethnic origin, some of whom have remained in the region of origin and others who migrated to areas where MS occurs at a different rate from the region of origin. It was first shown in South Africa that immigrants tend to adopt the low MS frequency patterns seen in the indigenous population. ${ }^{9}$ This trend has been reported for migration to and from both high and low risk prevalence regions. ${ }^{9-11.48-50}$ However, not all of these findings can be accepted unreservedly, as illustrated by the Israeli studies ${ }^{10.11}$ which concluded that age at migration was an important risk factor for developing MS. However, these data assume that migrating children and adults are a homogeneous population, yet recent work ${ }^{51}$ suggests that this may be incorrect. The prevalence of MS is clearly higher among Ashkenazi (European) Jews than Sephardic (African/Asian) Jews. That these two groups are genetically different is shown by differences in the incidence and prevalence of many known genetic disorders. ${ }^{52}$ After World War II, the period used for the Israeli immigration studies, it is likely that there were relatively more Sephardic Jews among migrating children and relatively more Ashkenazi Jews among migrating adults because of the holocaust which tended to spare whole Sephardic families living in Spain, Turkey and Bulgaria (personal communication, Israeli consul, Toronto). On the other hand, a relatively high proportion of Ashkenazi Jews may have migrated as single adults or as partial family units. These considerations may conceivably account in part for the observation that those who immigrated to Israel as children had a lower risk to subsequently develop MS compared to those who immigrated at a later age.

Another weaknesses in migration studies is the relatively small size of the study groups. As well, it is difficult to compare studies done at different times, even in the same geographic region, because the prevalence of MS is steadily rising in most areas due to improved diagnostic techniques and survival. ${ }^{26.28}$ For example, few neurologists were in practice at the time of the initial study on immigrants to South Africa ${ }^{9}$ and fewer than 20 cases of MS were identified in the most informative groups. A more recent study of children born in the United Kingdom to parents who immigrated from the West Indies found that the prevalence of MS approaches that seen in native Londoners. ${ }^{50}$ However, the study was based on a small number of index cases drawn from a population diffused throughout a vast metropolis in which the total number of "at risk" individuals is difficult to define.

In conclusion, results from migration studies are not easily interpreted and are often ambiguous. Genetic and environmental explanations of observed results are not mutually exclusive.

\section{Geographic Clusters}

In reviewing epidemiological studies from around the world, there are numerous reports of "clusters" or "hot-spots" where several cases of MS have occurred at a similar point in time, grew up together or were exposed to a specific locale over the same period of time. Examples of reported clusters include Key West (Florida), ${ }^{53}$ Henribourg (Saskatchewan), ${ }^{54}$ workers in a zinc-related manufacturing plant, ${ }^{55}$ Colchester County (Nova
Scotia), ${ }^{56}$ Vaasa (Finland), ${ }^{57}$ Hordaland (Norway), ${ }^{58}$ Los Alamos County (New Mexico) ${ }^{59}$ and Mansfield (Massachusetts). ${ }^{60}$ Analysis of such clusters is less than straightforward since the denominator (the number of groups from which the identified high risk subgroup has been selected) is unknown, but can be anticipated to be large. The highest known prevalence rates for MS are in the Orkney Islands (309 per 100,000 population) and Shetland Islands (184 per 100,000 population). ${ }^{61}$ Within the Orkney Islands, clustering of cases in time and space have been reported. ${ }^{62}$ Lifetime data showed temporal/spatial clustering of MS patients at least 21 years prior to disease onset and just prior to onset. Each of the two time clusters appeared on three separate islands. No clustering could be demonstrated in the Shetland Islands.

It has not yet been possible to explain clusters. It is, however, important to consider such reports as thoroughly as possible in a continuing attempt to identify causal agents and also to verify the veracity of a reported cluster. For example, a recent report of a cluster in Ohio was found to be erroneous after thorough investigation of reportedly affected individuals. ${ }^{63}$

\section{Epidemics}

There have been two MS "epidemics" identified since World War II. The first and most dramatic has been in the Faroe Islands, whose population is derived largely of Scandinavian ancestry. Prior to World War II, there were no reported cases of MS in the Faroe Islands, but 46 cases were identified from 1943 to 1982 . ${ }^{64.65}$ The point prevalence was reported as 41 in 1950. 64 in 1961, 38 in 1972 and 34 in 1977. These data have been interpreted to indicate a point-source epidemic temporally related to the stationing of approximately 8,000 British troops on the Islands during World War II. However, although the investigations in these studies made impeccable use of available methodology, their interpretation has been open to criticism $^{66.68}$ and rebuttal. ${ }^{69} \mathrm{~A}$ major issue yet to be clarified is why British troops have not transmitted MS to many other exposed and previously virgin populations, such as in Africa, or why new cases of MS have ceased to occur in the Faroe Islands.

A second, but less convincing epidenic reportedly occurred in Iceland, also in relation to the stationing of British troops during World War II. The annual average incidence of MS during the period 1945 to 1954 was 3.2 per 100,000 population compared with incidence rates of 1.6 per 100,000 population for 1923 to 1944 and 1.9 per 100,000 population for 1955 to $1974 .^{70}$ Kurtzke and colleagues ${ }^{69}$ conclude that the incidence of MS during the period 1945 to 1954 meets the criteria for a point-source epidemic whose tail thereafter merges with the baseline for Iceland. However, the situation in Iceland differs from that in the Faroe Islands in that MS did exist prior to the occupation by British troops. As the first neurologist in Iceland only arrived in $1942,{ }^{70}$ this may have influenced the apparent increase in MS over the next few years, particularly among younger Icelanders.

Despite these reported epidemics, the identity of the putative infectious agent(s) remains unknown. Many observers remain unconvinced that these tantalizing data have proven transmissibility. Finally, the action of a transmissible agent is only one possible explanation for the observed findings. It is possible that the introduction of a large number of common viruses into a virgin susceptible population could serve to trigger an apparent epidemic without the implication of a specific transmissible agent. 


\section{Sex Ratio}

Females are more susceptible to MS by a factor which varies among surveys but approaches $2: 1$ in population studies. ${ }^{71}$ Males have a mean age of onset approximately a year or two later than females and also have a greater tendency for a progressive course from disease onset. ${ }^{72.74}$ The female preponderance is even more pronounced $(3: 1)^{75}$ if MS onset is before age 16. It has been suggested that as these figures are based on prevalence rates, they may reflect differential survival among females and males. However, a recent study on cause of death among patients attending Canadian MS Clinics found that survival did not differ according to sex. ${ }^{76}$ It is thus quite likely that factors other than sex-related influences on mortality explain the observed sex ratio in MS. Differences in immune responsiveness may be influenced by neuroendocrine interactions with the immune system. Weitkamp ${ }^{77}$ reviewed the literature and found that relatives (siblings, second-degree relatives, first cousins) concordant for MS were more often of the same sex, but this was not confirmed. ${ }^{78}$ The observation of Weitkamp ${ }^{77}$ does not necessarily imply a genetic/hormonal mechanism among siblings since such pairs may in fact have more environmental sharing compared with unlike-sex siblings. ${ }^{79}$ Unlike-sex siblings of MS patients also have a significantly higher risk to develop MS compared with the general population..$^{9.10}$

\section{AGE OF ONSET}

Diagnostic criteria ${ }^{3}$ now define the age of onset range as 10 to 59 years, extending the upper age limit from age $50 .{ }^{80}$ The mean age of onset is from 29 to 33 , being slightly younger in females. ${ }^{77}$ Several studies have reported that approximately $0.3 \%$ of patients have the clinical onset under age $10 .^{75}$ Duquette and colleagues ${ }^{75}$ reviewed childhood MS (onset before age 16). They found that childhood MS is more frequent among females $(75.2 \%)$ and often follows a relapsing-remitting course $(56 \%)$. The initial attack, from which there is usually complete recovery, tends to involve afferent structures of the central nervous system and the progress is usually slow. Conversely, MS may onset after age $59,{ }^{81.82}$ even into the eighth decade. The differential diagnosis is usually less straightforward in older patients who tend to have a chronically progressive course similar to that characteristic of many degenerative diseases seen in older age. For example, older patients could have occlusive cerebrovascular disease which can occasionally produce a stepwise and fluctuating clinical course that can mimic MS.

Recent studies at the MS Clinics in London and Vancouver ${ }^{83.84}$ have found a correlation in age of onset among sibling pairs concordant for MS. In addition, a stronger correlation was observed when concordant monozygotic twin pairs were compared with non-twin MS sibling pairs, ${ }^{83}$ suggesting that age of onset in MS is partly under genetic control.

\section{Precipitating FaCtors}

There are a number of factors which have been proposed as influencing the onset of symptoms or worsening of MS. These include diet ${ }^{85}$ and heavy metals ${ }^{55.86}$ as well as trauma, emotional stress, lumbar puncture, surgery and anaesthesia, pregnancy, exertion, fatigue and heat. ${ }^{87}$ However, none of these are universal precipitating factors and several are supported only by methodologically weak or unconfirmed studies, often of an anecdotal nature.

\section{Infection}

Identification of clusters and epidemics has often been interpreted as support for the role of infectious agents as causal factors in the onset of MS. Canine distemper virus was proposed as a leading candidate in the 1970 's ${ }^{88}$ but subsequent case-control studies have failed to support this. ${ }^{89-91}$ However, surveys of antibodies to different viruses in various MS populations worldwide have shown that on average, MS patients have high antibody levels to many viruses, measles included. Therefore, existing data give little support to the theory that MS results from exposure to a single, relatively rare virus.

The role of infectious agents in precipitating the clinical onset or relapses of MS remains unresolved. Most research in this area has been based on retrospective data and recall bias becomes a factor. It has been estimated that the onset of MS was preceded by a reported infective disease in about $10 \%$ of cases. ${ }^{87}$ Sibley and colleagues ${ }^{92}$ found that minor respiratory tract infections preceded $27 \%$ of MS relapses. Another report ${ }^{93}$ found that chronic sinus infection was significantly associated with the timing of MS relapses, as well as with the age and season when these occurred. Sibley and Foley ${ }^{94}$ reported a seasonal increase in MS relapses in Ohio during the months when respiratory infections are common. Subsequent work ${ }^{95}$ in London, Ontario has confirmed this pattern for disease onset. It is however not clear whether these seasonal influences are related to viral infection or to some other concomitant. Does the same factor(s) influencing seasonal variation also account for some of the geographic gradient? The relationship between infectious agents and MS remains unclear. It is conceivable that infection in general may act as a non-specific trigger for the immune system by initiating the onset of MS or by triggering a relapse.

\section{Trauma and Stress}

The role of trauma as a possible precipitating factor in MS was first raised by $\mathrm{Charcot}^{2}$ who hypothesized an association between MS onset and exposure to cold, falling, illness or stress. Although clinical experience suggests that trauma, physical stress and/or emotional stress may be associated with the onset or relapse of MS, any causal relationship has yet to be clearly and repeatedly demonstrated. In a systematic prospective study of I30 MS patients and 82 age- and sex-matched controls, Bamford and colleagues ${ }^{96}$ failed to prove a statistical association between traumatic events and MS relapses, although individual case reports were noted. In reporting MS relapses in relation to trauma, recall bias is always a concern and often the trauma as in a fall has been symptomatic rather than causal. ${ }^{97}$

\section{Pregnancy}

The original and classical study on the association between pregnancy, delivery and MS relapses was done by Millar and colleagues $^{98}$ who found that the average relapse rate per pregnancy year (nine months gestation plus three months following delivery) was 0.265 , elevated compared with the rate of 0.10 relapses per year experienced by women who did not have pregnancies. It is troublesome that neither of these rates approached the 0.5 to 1.4 attack(s) per year found in prospective studies. ${ }^{99-101}$ Subsequent retrospective studies continued to confirm the observation that the period following delivery posed the highest 
risk for a MS relapse, but that gestation itself was relatively quiescent with respect to disease activity. ${ }^{87.102}$ As with other studies on MS, the major methodological problem with research on the relationship between MS and pregnancy has been the use of retrospective data with their inherent recall bias. The definition of an atlack has often been imprecise and not clearly separable from non-specific phenomena associated with the post-partum period. The unusually low relapse rates in the paper by Millar and colleagues serve to emphasize this drawback.

Fifty-five women presenting prior to the onset of pregnancy at the Vancouver MS Clinic were followed throughout successful pregnancies and for up to six months after delivery. ${ }^{103}$ Relapse rates for these women during the study period were compared. "Expected" rates ${ }^{104}$ were based on data for matched controls and the women themselves prior to becoming pregnant (self-controls). A gestational effect was only evident during the third trimester when the observed relapse rate was significantly less $(\mathrm{P}<0.05)$ than expected. The mean relapse rate for each of the two 3-month periods following delivery did not differ significantly from expected.

\section{Diseases Associated) with Multiple Sclerosis}

A number of diseases such as systemic lupus erythematosus, ${ }^{105}$ myasthenia gravis, ${ }^{106-108}$ ankylosing spondylitis, ${ }^{105.10 \% .110}$ inflammatory bowel disease 111 and scleroderma ${ }^{112}$ have been reported to be associated with MS. However, none of these reports has as yet been confirmed by appropriate and careful population-based surveys. The most that can be said is that MS does not protect individuals from the above conditions nor does it make those other disorders very much more likely to occur.

Every large MS centre can identify cases in which autoimmune diseases occur in MS patients and there is evidence that there are rare families in which there is a genetic predisposition to autoimmune diseases. ${ }^{113}$ In Olmsted County, a detailed survey derived relative risks ( $r r)$ for 17 autoimmune diseases including rheumatoid arthritis $(\mathrm{rr}=1.8)$ and autoimmune thyroid disease ( $r r=3.3$ ) in MS patients compared with controls. ${ }^{14-116}$ The only statistically significant result was for autoimmune thyroid disease (Hashimoto's thyroiditis and Graves' disease). Similar data were collected in London, Ontario for relatives of 194 MS patients and spousal controls. The results were that there was an increased frequency of poliomyelitis and thyroid disease and a mild reduction of cancer in the MS families compared with controls (A. Rudd, G.C. Ebers - unpublished data). This does not appear to represent a promising avenue of exploration. The data serve rather more to underscore the remarkable organ specificity of MS than to support the hypothesis of some general autoimmune diathesis. It is beyond the scope of this review to discuss all but a selected few possible disease associations with MS.

\section{Diabetes Mellitus}

The study in Olmsted County, Minnesota reported a relative risk of 2.5 in MS patients for diabetes mellitus, ${ }^{114}$ but this was not statistically significant. Warren and Warren ${ }^{117}$ reported a higher association of diabetes mellitus in both MS patients and their relatives compared with controls.

\section{Neoplasia}

The study in Olmsted County ${ }^{1 / 8}$ reported a relative risk of 1.4 in MS patients for neoplasia, but this was not statistically signifi- cant. Neoplasia in MS has been reported to occur as expected compared with controls by some ${ }^{28.119}$ whereas others have found an increased rate. Zimmerman and Netsky ${ }^{120}$ reported a $20 \%$ incidence of malignant tumours in 50 autopsicd cases of MS, including two brain tumours. Others have also reported concurrent MS and primary brain tumours. ${ }^{120-123}$ An autopsy series of 120 cases $^{125}$ found neither an increase in the rate of ncoplasia among MS patients compared with general controls nor any cases with brain tumours. A recent study ${ }^{76}$ found that neoplasia was identified as an underlying cause of death significantly less often among MS patients than expected. While it is conceivable that changes in the immune system may "protect" MS patients from neoplasia, a more likely explanation for these data is that neoplasia is less readily diagnosed in MS patients not having autopsies since the symptoms of neoplasia may often be attributed to MS or be less likely to be investigated in disabled patients. In any event, these studies provide important bases for comparison now that cytotoxic agents have achieved relatively widespread usage.

\section{Uveitis}

Uveitis in different forms has been reported in association with various infectious and autoimmune diseases including Behçet's disease, toxoplasmosis, ankylosing spondylitis, sarcoidosis, syphilis and MS. ${ }^{87}$ Uveitis has been reported in up to five percent of patients in studied series ${ }^{87}$ and an even higher rate is found for perivenous sheathing. The main implications here are the associations with infective/autoimmune disorders and the recognition that the uveal tract constitutes an organ which is not myelinated but which participates in the inflammatory process in a substantial proportion of patients.

\section{SUMmary}

\section{Prevalence - Worldwide}

In a review of the epidemiology of MS, it is tempting to visually represent the worldwide prevalence of MS in a single, comprehensive map. However, the reader may find such a map more misleading than it is meaningful. Existing prevalence and incidence studies for most countries are not comparable and must be influenced by temporal differences as well as differences in health care systems, neurological expertise and even cultural practices. For these reasons, we chose to list prevalence data alphabetically by country in a table (Table 2) so that it is retrievable for reference with hopefully less of an implication that these studies can be directly compared.

We decided to illustrate some of the consistent, although somewhat contradictory, conclusions drawn from worldwide prevalence studies using contemporaneous data from the most informative comparative studies.

\section{1) Latitude Effect}

Several countries exhibiting relative racial homogeneity show a north-south gradient (e.g. Australia, New Zealand); - see Figure 3.

However, there are a number of exceptions to the north-south gradient when regions of different ethnic derivation are included, as shown by the following two examples. The first example is Sicily and Malta which were simultaneously subjected to a prevalence study ${ }^{14.15}$ by the same investigator. Figure 1 shows the bottom part of the ltalian "boot" and the two islands in the 


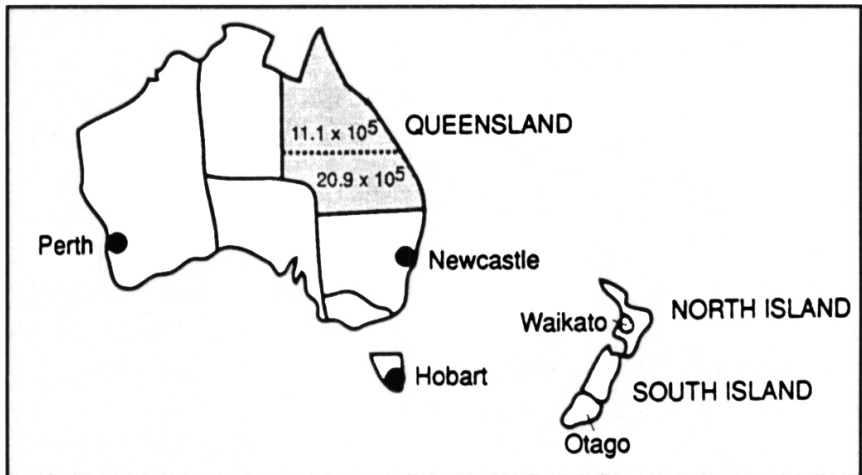

Figure 3: Comparison of Prevalence Rates for Australia and New Zealand.

\begin{tabular}{lcl} 
& Prevalence per 10 & Reference \\
\cline { 2 - 3 } Australia & & \\
Queensland & 18.3 & Hammond et al. ${ }^{23}$ \\
Perth & 29.9 & Hammond et al..$^{23}$ \\
Newcastle & 36.5 & Hammond et al..$^{23}$ \\
Hohart & 75.6 & Hammond et al..$^{23}$ \\
New Zealand & & \\
North Island, Waikato & 27.9 & Skegg et al..$^{1+3}$ \\
South Island, Otago & 79.4 & Skegg et al..$^{143}$
\end{tabular}

Mediterranean. The second example is in North America where five recent prevalence studies using similar methodology demonstrate an almost four-fold difference in prevalence (see Fig. 2). The rate for Rochester, Minnesota closely approximates rates for Northeast Scotland and the Shetland/Orkney Islands;

2) Individuals from the same ethnic derivation have either the similar prevalence or have very different prevalence rates in widely separated geographical areas.

The former is illustrated by Minnesota and Scandinavia and the latter by the United Kingdom, Northern Australia and South Africa;

\section{3) Specific resistant isolates are shown to exist regardless of latitude.}

The sum total distribution of prevalence information for Orientals in North America leads to the almost inescapable conclusion that the geography of MS cannot be explained by any single known environmental factor in isolation. Similarly, it seems very unlikely that the distribution of any genetic factor(s), singly or in combination, could account for the observed worldwide distribution of MS.

\section{Conclusions}

It seems appropriate at this point to refrain from any further attempts to force an exclusively genetic or environmental explanation on an abundant collection of facts which simply will not accommodate them. It is timely that any further epidemiological studies be controlled as far as possible for genetic factors and that populations be selected for study in which this possibility is optimized. By doing this, re-examination of a number of individual environmental factors may then prove informative.
Table 2: MS Prevalence: Alphabetical Listing by Countrya,b

\begin{tabular}{|c|c|c|c|}
\hline Country & $\begin{array}{c}\text { Prevalence } \\
\text { Date (Period) }\end{array}$ & $\begin{array}{c}\text { Prevalence/ } \\
100,000 \\
\text { Populatione }\end{array}$ & Reference \\
\hline \multicolumn{4}{|l|}{ Australia } \\
\hline Perth & June 30,1981 & 29.9 & Hammond et al. ${ }^{2}$ \\
\hline Newcastle & June 30,1981 & 36.5 & Hammond et al. ${ }^{23}$ \\
\hline Hobart & June 30,1981 & 75.6 & Hammond et al. ${ }^{2 ?}$ \\
\hline $\begin{array}{l}\text { State of Queensland } \\
\text { Austria }\end{array}$ & June 30,1981 & 18.3 & Hammond et al. ${ }^{23}$ \\
\hline Vienna & & 41.6 & Bauer ${ }^{13}$ \\
\hline Upper Austria & & 29.4 & Bauer ${ }^{13}$ \\
\hline Lower Austria & & 21.7 & Bauer $^{13}$ \\
\hline Belgium & 1983 & $80-100$ & Bauer ${ }^{13}$ \\
\hline Bulgaria & & 21.2 & Bauer $^{13}$ \\
\hline \multicolumn{4}{|l|}{ Canada } \\
\hline Saskatoon, SK & Jan. 1, 1977 & 134.0 & Hader $^{32}$ \\
\hline Newfoundland & March 31, 1985 & 55.2 & Pryse-Phillips ${ }^{34}$ \\
\hline British Columbia & July 1,1982 & 117.2 & Sweeney et al. ${ }^{26}$ \\
\hline London, Ontario & Jan., 1984 & 94 & Hader et al. ${ }^{29}$ \\
\hline Barrhead, Alberta & Jan. 1,1990 & 196 & $\begin{array}{c}\text { Warren and } \\
\text { Warren }\end{array}$ \\
\hline Cardston, Alberta & & 87 & Klein et al. ${ }^{127}$ \\
\hline Crowsnest Pass, Al & berta & 202 & Klein et al. ${ }^{127}$ \\
\hline \multicolumn{4}{|c|}{ Czechoslovakia (Western) } \\
\hline Prague & & 67 & Bauer $^{13}$ \\
\hline Northern Bohemia & & 108 & Bauer ${ }^{13}$ \\
\hline Denmark & 1965 & 101 & Bauer ${ }^{13}$ \\
\hline
\end{tabular}

Faroe Islands (See section in chapter on "epidemics")
France

Brittany

Chalon-sur-Saone

Avignon

Haute Pyrenees

Finland

Uusima (South)

Vaasa (West)

1979

Germany

Federal Republic

Hesse

Democratic Republic

Rostock

Halle

Greece

Macedonia and Thrace

Hong Kong

Hungary

Hungarians

Gypsies

1976-1978

1979

Dec. 31,1980 Dec. 31,1980

Iceland

See section in chapter on "epidemics"

India

Zoroastrians (Parsis)

March 1, 1988

Dec. 31.1984

Dec. 31,1987

Sept. 1949

Aug. 31, 1981

Zoroastrians (Parsis)

(Poona)

March 1. 1988

Israel

Immigrants

Europeans

\section{6}

58

Jan. 1, 1966
49

39.6

54

5

9.6

91

68

58.3

69.1

42.6

10

29.5

0.88

Milonas et al. ${ }^{130}$

Yu et al. ${ }^{131}$

37
2

2

Palffy ${ }^{1.32}$

Palffy ${ }^{1.32}$

Gallou et al. ${ }^{12 k}$

Bauer $^{13}$

Bauer $^{13}$

Bauer $^{13}$

Bauer $^{13}$

Bauer $^{13}$

Bauer $^{13}$

Bauer ${ }^{13}$

Bauer $^{13}$

$$
\text { Europeans }
$$

\section{Wadia and Bhatia ${ }^{133}$ \\ Wadia and Bhatia ${ }^{133}$}

Leibowitz
et al. ${ }^{134}$


Table 2: continued

\begin{tabular}{cccc}
\hline \hline & & Prevalence/ \\
Country & Prevalence & 100,000 \\
Date (Period) & Population $^{c}$ & Reference \\
\hline
\end{tabular}

\section{Israel}

Afro-Asians

Native-born Israelis Jan. 1, 1965

Europeans

Afro-Asians

Italy

Barbagia, Sardinia

Sicily, Enna

Valle d'Aosta

Oct 24,1981

Jan. 1, 1975

Dec 31, 1985

Japan

Korea

Busan

1971-1981

Seoul

1958-1966

Kuwait

1981-1983

Libya

July 1,1984

Luxembourg No formal survey Malaysia

1968-1986

Malta

Mexico

(Government workers and their families)

\section{New Zealand}

Waikato (North lsland)

Otago and Southland

(South Island)

Norway

Hordaland County Jan 1, 1983

Möre \&

Romsdal County Jan 1, 1985

Poland (Western) $\quad$ Dec 31, 1981

Portugal

Romania

Brasov, Transylvania

Cluj, Transylvania

Bucharest

Danube (Southern Regions)

Saudi Arabia

Jan. 1983 -

Dec. 1986

South Africa

White South Africans

(English-speaking)

(Africaans-speaking)

1960

1960

Spain

Lanzarote (Canary

Islands)

Dec. 21,1987

Malaga

June 30,1984

Sweden

Switzerland

Basel

Bern

$\begin{array}{rr}12.7 & \text { Dean }^{9} \\ 3.6 & \text { Dean }^{9}\end{array}$

$6.8 \quad$ Leibowitz
et al. ${ }^{134}$

$8.8 \quad$ Leibowitz

et al. ${ }^{134}$

2.7 Leibowitz et al. ${ }^{134}$

$65.3 \quad$ Granieri et al.44

53 Dean et al. ${ }^{15}$

39 Sironi et al. ${ }^{135}$

1-4 Kurojwa et al. ${ }^{136}$

$1.8 \quad$ Kim and $\mathrm{Kim}^{137}$

2.4 Park ${ }^{138}$

8.3 Al-Din ${ }^{139}$

5.9 Radhakrishnan et al. ${ }^{140}$

Bauer $^{13}$

$\operatorname{Tan}^{141}$

Vassallo et al. ${ }^{14}$

$1.5 \quad$ Alter ${ }^{142}$

$27.9 \quad$ Skegg et al..$^{143}$

$79.4 \quad$ Skegg et al. ${ }^{14.3}$

$59.8 \quad$ Larsen et al. ${ }^{41}$

$75.4 \quad$ Midgard et al. ${ }^{42}$

42.87 Wender et al. ${ }^{36}$

15 Bauer ${ }^{13}$

$46 \quad$ Bauer $^{13}$

$43 \quad$ Bauer $^{13}$

$79.4 \quad$ Bauer $^{13}$

$<6 \quad$ Bauer $^{13}$

Yaquib and

Daif ${ }^{144}$

$8 \quad$ Daif $^{144}$

15

10.9

Garcia et al. ${ }^{46}$

130

51.4

106

55
Table 2: continued

\begin{tabular}{|c|c|c|c|}
\hline Country & $\begin{array}{c}\text { Prevalence } \\
\text { Date (Period) }\end{array}$ & $\begin{array}{c}\text { Prevalence/ } \\
100,000 \\
\text { Population }^{c}\end{array}$ & Reference \\
\hline \multicolumn{4}{|c|}{ Switzerland } \\
\hline Valais & & 25 & $\begin{array}{l}\text { Bartschi- } \\
\text { Rochaix }\end{array}$ \\
\hline Taiwan & May, 1975 & 0.95 & Hung et al..$^{147}$ \\
\hline Tunis & & 10 & Ben Hamida $^{148}$ \\
\hline
\end{tabular}

United Kingdom

England

London, Borough of Sutton

Jan. 1, 1985

115

Williams \&

McKeran ${ }^{149}$

Wales

South-Eası Wales

(South Glamorgan Jan. 1, 1985

Swingler \& Compston ${ }^{150}$

Scotland

North-East Scotland

(Grampian Region) Dec. 1, 1980

144

Phadke \&

Downie ${ }^{151}$

$\begin{array}{lrcc}\text { Shetland Islands } & \text { April 30,1984 } & 170 & \text { Cook et al. }{ }^{152} \\ \text { Orkney Islands } & \text { Sept. 21, 1983 } & 224 & \text { Cook et al. }{ }^{153} \\ \text { Outer Hebrides } & \text { July 1, 1979 } & 97.3 & \text { Dean et al. }{ }^{154}\end{array}$

United States

Hawaii

"Orientals" $\quad$ Jan. 1, $1969 \quad 8.8 \quad$ Alter et al. 155

"Caucasians" Jan. 1, $1969 \quad 10.5 \quad$ Alter et al. ${ }^{155}$

California

Los Angeles (Whites,

Los Angeles-born) April 1, $1970 \quad 22 \quad$ Visscher et al. ${ }^{1.57}$

Washington (Whites born

in King-Pierce

Counties) April $1,1970 \quad 69 \quad$ Visscher et al. ${ }^{157}$

Minnesota, Rochester Jan. 1, $1985 \quad 173 \quad$ Wynn et al. ${ }^{39}$

USSR

Moscow (based on

incomplete survey)

1973

32

Batuer ${ }^{13}$

Consensus at the International Federation of Multiple Sclerosis Societies. Hamburg, 1985 is that the prevalence rates for MS in the USSR probably parallel those in the corresponding latitudes of western Europe (Bauer ${ }^{13}$ )

Yugoslavia

Croatia

June 30,1986

143.5

Sepcic et al. ${ }^{15 x}$

"The reader is referred to the appropriate references. These rates are not necessarily comparable with each other, but should provide the most upto-date information known for the country. Studies vary on the diagnostic criteria, ascertainment and year of study.

bThis is not meant to be a comprehensive list of every prevalence survey ever conducted in a given country.

"Age-specific prevalence rates given, when available. Studies vary on the diagnostic criteria for inclusion in the prevalence rate. 


\section{ACKNOWLEDGEMENTS}

The authors would like to thank Jean Turnbull for her assistance with the literature search. This work was funded in part by the Multiple Sclerosis Society of Canada and the Multiple Sclerosis Society of Canada, British Columbia Division.

\section{REFERENCES}

I. Fox JP, Hall CE, Elveback LR. Epidemiology: Man and Disease. Toronto: The Macmillan Co, 1970: 185.

2. Charcot JM. Lectures on the Diseases of the Nervous System. Vol 1. (Translated by G. Sigerson). London: The New Sydenham Society, 1877: 157-222.

3. Poser CM, Paty DW, Scheinberg L, et al. New diagnostic criteria for multiple sclerosis. Guidelines for research protocols. In: Poser CM, Paty DW, Scheinberg L, Ebers GC, eds. The Diagnosis of Multiple Sclerosis. New York: Thieme-Stratton Inc, 1984: 225-233.

4. Poskanzer DC, Schapira K, Miller H. Multiple sclerosis and poliomyelitis. The Lancet 1963; ii: 917-921.

5. Dupont B, Lisak RP, Jersild C, et al. HLA antigens in black American patients with multiple sclerosis. Transpl Proc 1976; 91 (Suppl 1): 181-185.

6. Hader WJ, Feasby TE, Noseworthy JH, et al. Multiple sclerosis in Canadian Native People. Neurology 1985; 35 (Suppl 1): 300.

7. McCall MG, Brereton T Le G, Dawson A, et al. Frequency of multiple sclerosis in three Australian centres, Perth, Newcastle and Hobart. J Neurol Neurosurg Psychiatry 1968; 31: 1-9.

8. Antonovsky A, Leibowitz U, Medalie JM, et al. Reappraisal of possible aetological factors in multiple sclerosis. Am J Public Health 1968; 58: 836-848.

9. Dean G. Annual incidence, prevalence and mortality of MS in white South African-born and in white immigrants to South Africa. Br Med J 1967; 2: 724-730.

10. Alter M, Hapern L, Kurland LT, et al. Multiple sclerosis in Israel: prevalence among migrants and native inhabitants. Arch Neurol 1962; 7: 253.263

11. Alter M, Leibowitz U, Speer J. Risk of multiple sclerosis related to age of immigration to Israel. Arch Neurol 1966; 15: 234-237.

12. Kurtzke JF. A reassessment of the distribution of multiple sclerosis. Part One. Acta Neurol Scand 1975; 51: 110-136.

13. Bauer HJ. Mulıiple sclerosis in Europe. Symposium Report. J Neurol 1987; 234: 195-206

14. Vassallo L, Elian M, Dean G. Multiple sclerosis in southern Europe. II. Prevalence in Malta in 1978. J Epidemiol Comm Health 1979; 33: 111-113.

15. Dean G, Grimaldi G, Kelly R, et al. Multiple sclerosis in southern Europe. I. Prevalence in Sicily in 1975. J Epidemiol Comm Health 1979; 33: 107-110.

16. Kurtzke JF. A reassessment of the distribution of multiple sclerosis. Part Two. Acta Neurol Scand 1975; 51: 137-157.

17. Davenport CB. Multiple sclerosis from the standpoint of geographic distribution and race. Arch Neurol 1922; 8: 51-58.

18. Bing R, Reese $H$. Die Multiple Sklerose in der Nordestschweiz. Schweiz Med Wochenschr 1926; 56: 30-34.

19. Allison RS. Disseminated sclerosis in North Wales: an inquiry into its incidence, frequency, distribution and other etiological factors. Brain 1931; 53: 301-430

20. Alter $M$, Leewenson $R$, Harshe $M$. The geographic distribution of multiple sclerosis: an examination of mathematical models. J Chron Dis 1973; 26: 755-767.

21. Kurtzke JF. Geography in multiple sclerosis. J Neurol 1977; 215: 126.

22. Hammond SR, de Wytt C, Maxwell LC, et al. The epidemiology of multiple sclerosis in Queensland, Australia. J Neurol Sci 1987; 80: 185-204.

23. Hammond SR, McLeod JG, Millingen KS, et al. The epidemiology of multiple sclerosis in three Australian cities: Perth, Newcastle and Hobart. Brain 1988; 111: 1-25.

24. Leiter, E.H., Serreze, D.V., Prochazka, M. The genetics and epidemiology of diabetes in NOD mice. Immunol Today 1990; 11: 147-149.
25. Ebers GC, Sadovnick AD. The role of genetic factors in multiple sclerosis susceptibility: a critical review. J Neuroimmunol, in press, 1993.

26. Sweeney VP, Sadovnick AD, Brandejs V. Prevalence of multiple sclerosis in British Columbia. Can J Neurol Sci 1986; 13: 47-51.

27. Westlund KB, Kurland LT. Studies on multiple sclerosis in Winnipeg, Manitoba and New Orleans, Louisiana. I. Prevalence. Comparison between the patient groups in Winnipeg and New Orleans. Am J Hyg 1953; 57: 380-396.

28. Stazio A, Kurland LT, Bell GL, et al. Multiple sclerosis in Winnipeg, Manitoba. Methodological consideration of epidemiologic survey: ten-year follow-up of a community-wide study and population re-survey. J Chron Dis 1964; 17: 415-438.

29. Hader WJ, Elliot M, Ebers GC. Epidemiology of multiple sclerosis in London and Middlesex County, Ontario, Canada. Neurology 1988; 38: 617-621.

30. Alter M, Allison RS, Talbert OR, et al. The geographic distribution of multiple sclerosis. A comparison of prevalence in Charleston County, South Carolina and Halifax County, Nova Scotia. II. Prevalence in Halifax County, Nova Scotia. NS Med Bull 1960; 39: 203-210.

31. White DN, Wheelan L. Disseminated sclerosis. A survey of patients in the Kingston, Ontario, area. Neurol 1959; 9: 256-272.

32. Hader WJ. Prevalence of multiple sclerosis in Saskatoon. Can Med Assoc J 1982; 127: 295-297.

33. Bennett L, Hamilton R, Neutel Cl, et al. Survey of persons with multiple sclerosis in Ottawa, 1974-1975. Can J Public Health 1977; 68: 141-147.

34. Pryse-Phillips WEM. The incidence and prevalence of multiple sclerosis in Newfoundland and Labrador, 1960-1984. Ann Neurol 1986; 20: 323-328.

35. Cendrowski W, Wender M, Dominik W, et al. Epidemiological study of multiple sclerosis in Western Poland. Eur Neurol 1968; 2: $90-103$.

36. Wender M, Pruchnik-Grabowska D, Hertmanowska $H$, et al. Epidemiology of multiple sclerosis in Western Poland. Acta Neurol Scand 1985; 72: 210-217.

37. Percy AK, Nobrega FT, Okazaki $\mathrm{H}$, et al. Multiple sclerosis in Rochester, Minn: a 60-year appraisal. Arch Neurol 1971; 25: 105-111.

38. Kranz JMS, Kurland LT, Schuman LM, et al. Multiple sclerosis in Olmsted and Mower Counties, Minnesota. Neuroepidemiology 1983; 2: 206-218

39. Wynn DR, Kurland LT, O'Fallon WM, et al. A reappraisal of the epidemiology of multiple sclerosis in Olmsted County, Minnesota. Neurology 1990; 40: 780-786.

40. Wynn DR, Rodriguez M, O'Fallon WM, et al. Update on the epidemiology of multiple sclerosis. Mayo Clinic Proc 1989; 64: 808-817.

41. Larsen JP, Aarli JA, Riise T. Western Norway, a high risk area for multiple sclerosis. A prevalence/incidence study in the county of Hordaland. Neurology 1984; 34: 1202-1207.

42. Midgard R, Riise T, Nyland $H$. Epidemiologic trends in multiple sclerosis in Möre and Romsdal, Norway. A prevalence/incidence study in a stable population. Neurology 1991: 41: 887-892.

43. Granieri E, Rosati G. Italy: A medium- or high-risk area for multiple sclerosis? An epidemiologic study in Barbagia, Sardinia, southern Italy. Neurology 1982; 32: 466-472.

44. Granieri E, Rosati G, Tola R, et al. The frequency of multiple sclerosis in Mediterranean Europe. An incidence and prevalence study in Barbagia, Sardinia, insular Italy. Acta Neurol Scand 1983; 68: 84-89.

45. Presthus J. Report on the multiple sclerosis investigations in WestNorway. Acta Psychiat Neurol Scand 1960; 35 (Suppl 147): 8892.

46. Garcia JR, Rodriguez S, Henriquez MS, et al. Prevalence of multiple sclerosis in Lanzarote (Canary Islands). Neurol 1989; 39: 265-267.

47. Gilbert JJ, Sadler M. Unsuspected multiple sclerosis. Arch Neurology 1983; 40: 533-536.

48. Kurtzke JF, Bui QH. Multiple sclerosis in a migrant population. II. Half-orientals immigrating in childhood. Ann Neurol 1980; 8: 256-260. 
49. Detels R, Visscher BR, Haile RW, et al. Multiple sclerosis and age at migration. Am J Epidemiol 1978; 108: 386-393.

50. Elian $M$, Nightingale S, Dean G. Multiple sclerosis among the United Kingdom born children of immigrants from the Indian Subcontinent, Africa and the West Indies. J Neurol Neurosurg Psychiatry 1990; 53: 906-911.

51. Biton V, Abramsky $O$. New study fails to support environmental factors in etiology of multiple sclerosis. Neurology 1986; 36 (Suppl 1): 184.

52. McKusick VA. Mendelian Inheritance in Man. 5th Edition. Baltimore: The John Hopkins University Press, 1978, pp IX.

53. Sheremata WA, Poskanzer DC, Withum DG, et al. Unusual occurrence on a tropical island of multiple sclerosis. The Lancet 1985; ii: 618.

54. Irvine DG, Schiefer HB, Hader WJ. Geotoxicology of multiple sclerosis: the Henribourg, Saskatchewan, cluster focus. Il. The soil. Sci Total Environment 1988; 77: 175-188.

55. Stein EC, Schiffer RB, Hall J, et al. Multiple sclerosis and the workplace: report of an industry-based cluster. Neurology 1987; 37: 1672-1677.

56. Murray TJ. An unusual occurrence of multiple sclerosis in a small rural community. Can J Neurol Sci 1976; 3: 163-166.

57. Kinnunen E. Multiple sclerosis in Finland: evidence of increasing frequency and uneven geographic distribution. Neurology 1984; 34: 457-461.

58. Larsen JP, Riise T, Nyland $\mathrm{H}$, et al. Clustering of multiple sclerosis in the county of Hordaland, Western Norway. Acta Neurol Scand 1985; 71: 390-395.

59. Hoffman RE, Zack MM, Davis LE, et al. Increased incidence and prevalence of multiple sclerosis in Los Alamos County, New Mexico. Neurology 1981; 31: 1489-1492.

60. Eastman R, Sheridan J, Poskanzer DC. Multiple sclerosis clustering in a small Massachusetts community, with possible common exposure 23 years before onset. N Engl J Med 1973; 289: 793794.

61. Poskanzer DC, Prenney LB, Sheridan JL, et al. Multiple sclerosis in the Orkney and Shetland Islands. I. Epidemiology, clinical factors and methodology. J Epidemiol Comm Health 1980; 34: 229-239.

62. Poskanzer DC, Walker AM, Prenney LB, et al. The etiology of multiple sclerosis: temporal-spatial clustering indicating two environmental exposures before onset. Neurology 1981; 31:708713.

63. Conomy JP, Namey M, Rudick R, et al. Multiple sclerosis in Galion, Ohio: a cluster in time or a cluster in space? Neurology 1989; 39 (Suppl1): 284 .

64. Kurtzke JF, Hyllested K. Multiple sclerosis in the Faroe Islands. I. Clinical and epidemiological features. Ann Neurol 1979; 5: 6-21.

65. Kurtzke JF, Hyllested K. Multiple sclerosis in the Faroe Islands. II. Clinical update, Iransmission, and the nature of multiple sclerosis. Neurology 1986; 36: 307-328.

66. Acheson ED. The pattern of the disease. In: Matthews WB, Acheson ED, Batchelor JR, Weller RO, eds. McAlpine's Multiple Sclerosis. New York: Churchill Livingstone, 1985: $22-$ 25.

67. Poser CM, Hibberd PL. Benedikz, et al. Analysis of the "epidemic" of multiple sclerosis in the Faroe Islands. I. Clinical and epidemiological aspects. Neuroepidemiology 1988; 7: 168-180.

68. Poser CM, Hibberd PL. Analysis of the "epidemic" of multiple sclerosis in the Faroe Islands. 1. Biostatistical aspects. Neuroepidemiology 1988; 7: 181-189.

69. Kurtzke JF, Hyllested K. Validity of the epidemics of multiple sclerosis in the Faroe Islands. Neuroepidemiology 1988; 7: 190227.

70. Kurtzke JF, Gudmundsson KR, Bergmann S. Multiple sclerosis in Iceland: I. Evidence of a postwar epidemic. Neurology 1982; 32: 143-150.

71. Acheson ED. Epidemiology of multiple sclerosis. Br Med Bull 1977; 33: 9-14.

72. Ebers GC. Multiple sclerosis and other demyelinating diseases. $I n$ : Asbury A, McKhann G, McDonald I, eds. Diseases of the Nervous System. Pennsylvania: WB Saunders Company, 1986: 1268-1281.
73. Weinshenker BG, Bass B, Rice GP, et al. The natural history of multiple sclerosis: a geographically-based study. I. Clinical course and disability. Brain 1989; 112: 133-146.

74. Weinshenker BG, Bass B, Rice GP, et al. The natural history of multiple sclerosis: a geographically-based study. 2 . The predictive value of the early clinical course. Brain 1989; 112: 14191428.

75. Duquette P, Murray TJ, Pleines J, et al. Multiple sclerosis in childhood: clinical profile in 125 patients. J Pediat 1987; 111: 359363.

76. Sadovnick AD, Ebers GC, Eisen K, et al. Cause of death in patients attending multiple sclerosis clinics. Neurology 1991; 41: 11931196.

77. Weitkamp LR. Multiple sclerosis susceptibility: interaction between sex and HLA. Arch Neurol 1983; 40: 399-401.

78. Sadovnick AD, Bulman DE, Ebers GC. Influence of gender on the susceptibility to multiple sclerosis in siblings. Arch Neurol 1991: 48: 586-588.

79. Grufferman S. Cole PG, Lukes RJ. Hodgkin's disease in siblings. N Engl J Med 1977; 296: 248-250.

80. Schumacher GA, Beebe G, Kibler RF, et al. Problems of experimental trials of therapy in multiple sclerosis: report by the panel on the evaluation of experimental trials of therapy in multiple sclerosis. Ann NY Acad Med 1965: 122: 552-568.

81. Matthews WB. Course and prognosis. In: Matthews WB, Acheson ED, Batchelor JR, Weller RO, eds. McAlpine's Multiple Sclerosis. New York: Churchill Livingstone, 1985: 49-52.

82. Noseworthy J, Paty DW, Wonnacott T, et al. Multiple sclerosis after age 50. Neurology 1983: 33: 1537-1544.

83. Bulman DE. Sadovnick AD, Ebers GC. Age of onset in siblings concordant for multiple sclerosis. Brain 1991: 114: 937-950.

84. Sadovnick AD, Hashimoto LL, Hashimoto SA. Heterogeneity in multiple sclerosis: comparison of clinical manifestations in relatives. Can J Neurol Sci 1990, 17: 387-439.

85. Swank RL. Multiple sclerosis, correlation of its incidence with dietary fat. Am J Med Sci 1951; 220: 421-430.

86. Butler EJ. Chronic neurological disease as a possible form of lead poisoning. J Neurol Neurosurg Psychiatry 1952; 15: 119-128.

87. Matthews WB. Some aspects of the natural history. In: Matthews WB, Acheson ED, Batchelor JR, Weller RO, eds. McAlpine's Multiple Sclerosis. New York: Churchill Livingstone, 1985: 73-95.

88. Cook SD, Dowling PC. A possible association between housepets and multiple sclerosis. The Lancet 1977: i: 980-982

89. Bunnell DH, Visscher BR, Detels R. Multiple sclerosis and house dogs: a case control study. Neurology 1979; 29: 1027-1029.

90. Poskanzer DC, Prenney LB, Sheridan JL. Housepets and multiple sclerosis. Lancet 1977; i: 1204.

91. Read D, Nassim D, Smith P, et al. Multiple sclerosis and dog ownership: a case-control investigation. J Neurol Sci 1982; 55: 359367.

92. Sibley WA, Bamford CR, Clark K. Clinical viral infections and multiple sclerosis. Lancet 1985; 1313-1315.

93. Gay D, Dick G, Upton G. Multiple sclerosis associated with sinusitis: case-controlled study in general practice. Lancet 1986; $i$ : 815-819.

94. Sibley WA, Foley JM. Infection and immunization in mutliple sclerosis. Ann NY Acad Sci 1965; 122: 457-468.

95. D'Hooghe MB, Ebers GC. A population-based study of seasonal onset of multiple sclerosis in London. Ontario. Abstract. Neurology 1989; 39 (Suppl 1): 284.

96. Bamford CR, Sibley WA, Thies $C$, et al. Trauma as an etiologic and aggravating factor in multiple sclerosis. Neurology 1981; 31: 1229-1234.

97. McAlpine D, Compston ND. Some aspects of the natural history of disseminated sclerosis. J of Med 1952; 21: 135-167.

98. Millar JHD, Allison RS, Cheesman EA, et al. Pregnancy as a factor influencing relapse in disseminated sclerosis. Brain 1959;82: 417-426.

99. Koopmans RA, Li DKB, Oger J J-F, et al. The lesion of multiple sclerosis: imaging of acute and chronic stages. Neurology 1989a; 39: $959-963$.

100. Willoughby EW. Grochowski E, Li DKB, et al. Serial magnetic resonance scanning in multiple sclerosis: a second prospective study in relapsing patients. Ann Neurol 1989; 25: 43-49. 
101. Isaac C, Li DKB, Genton M, et al. Multiple sclerosis: a serial study using MRI in relapsing patients. Neurology 1988; 38: 1511-1515.

102. Birk K, Ford C, Smeltzer S, et al. The clinical course of multiple sclerosis during pregnancy and the puerperium. Arch Neurol 1990; 47: 738-742.

103. Sadovnick AD, Paty DW, Hashimoto SA, et al. Multiple sclerosis and pregnancy: a prospective study. Abstract. Neurol 1990; 40 (Suppl 1): 141 .

104. Barnell GO, Justice NS, Somand ME, et al. COSTAR - a computer-based medical information system for ambulatory care. Proc IEEE 1979; 67: 1226-1237.

105. Holmes FF, Stubbs DW, Larsen WE. Systemic lupus erythematosus and multiple sclerosis in identical twins. Arch Intern Med 1967: 119: 302 .

106. Margolis LN, Graves RW. The occurrence of myasthenia gravis in a patient with multiple sclerosis. NC Med J 1945; 24: 243-244.

107. Aita JF, Snyder DH, Reichl W. Myasthenia gravis and multiple sclerosis: an usual combination of diseases. Neurology $1974 ; 24$ : 72-75.

108. Shakir RA, Hussuen JM, Trontelj JV. Myasthenia gravis and multiple sclerosis. J Neuroimmunol 1983; 4: 161-165.

109. Matthews WB. The neurological complications of ankylosing spondylitis. J Neurol Sci 1968; 5: 561-573.

110. Thomas DJ, Kendall MJ, Whitfield AGW. Nervous system involvement in ankylosing spondylitis. Br Med $\mathrm{J}$ 1974; 1: 148150.

111. Sadovnick AD, Paty DW, Yannakoulias G. Concurrence of multiple sclerosis and inflammatory bowel disease. $\mathrm{N}$ Engl $\mathrm{J}$ Med 1989: 321: 762-763.

112. Trostle DC, Helfrich D, Medsger TA Jr. Systemic sclerosis (scleroderma) and multiple sclerosis. Arthritis Rheum 1986; 29: 124-127.

113. Bias WB, Reveille JD, Beaty TH, et al. Evidence that autoimmunity in man is a Mendelian dominant trait. Am J Hum Genet 1986; 39: 584-602

114. Wynn DR, Codd MB, Kurland LT, et al. Multiple sclerosis: a population-based investigation of the association with possible autoimmune diseases and diabetes mellitus. Abstract. Neurology 1987; 37 (Suppl 1): 272.

115. Linos A, Worthington JW, O Fallon WM, et al. The epidemiology of rheumatoid arthritis in Rochester, Minnesota: a study of incidence, prevalence and mortality. Am J Epidemiol 1980; 111: 87-98.

116. Furszyfer J, Kurland LT, McConahey WM, et al. Epidemiologic aspects of Hashimoto's thyroiditis and Graves disease in Rochester, Minnesota (1935-1967), with special reference to temporal trends. Metabolism 1972; 3: 197-204.

117. Warren S, Warren KG. Multiple sclerosis and associated diseases: a relationship to diabetes mellitus. Can J Neurol Sci 1981: 8: 35-39.

118. Wynn DR, Codd MB, Kurland LT, et al. Multiple sclerosis: a population-based investigation of the association with neoplastic disorders. Abstract. Neurology 1987; 37 (Suppl 1): 151.

119. Sibley WA, Banford CR, Laguna JF. Anamnestic studies in multiple sclerosis: a relationship between familial multiple sclerosis and neoplasia. Neurology 1978; 28: 125-128.

120. Zimmerman HM, Netsky MG. The pathology of multiple sclerosis. Res Publ Assoc Res Nerv Ment Dis 1950; 28: 271-312.

121. Castaigne P. Escourelle R, Brunet P, et al. Reticulosarcome cerebral primitif associe a des lesions de sclerose en plaques. Res Neurol 1974: 130: 181-188.

122. Currie S. Urich H. Concurrence of multiple sclerosis and glioma. J Neurol Neurosurg Psychiatry 1974; 37: 598-605.

123. Reagan TJ, Frieman IS. Multiple cerebral gliomas in multiple sclerosis. J Neurol Neurosurg Psychiatry 1973; 36: 523-528.

124. Lynch PG. Multiple sclerosis and malignant glioma. Br Med J 1974; 3: 577. Poskanzer DC, Prenney LB, Sheridan JL, Kondy JY. Multiple sclerosis in the Orkney and Shetland Ishands. I. Epidemiology, clinical factors and methodology. J Epidemiol and Comm Health 1980; 34: 229-239.

125. Allen IV, Millar JHD, Hutchinson MJ. General disease in 120 necropsy-proven cases of multiple sclerosis. Neuropathol App Neurobiol 1978; 4: 279-284.

126. Warren S, Warren KG. Prevalence of multiple sclerosis in Barrhead County, Alberta, Canada. Can J Neurol Sci 1992; 19: $72-75$.
127. Klein GM, Seland TP, Barclay L, Orman AV. An epidemiological study of multiple sclerosis in the Crowsnest Pass and Cardston regions of southern Alberta. Can J Neurol Sci 1990; 17: 241.

128. Gallou M, Madigand M, Masse L, et al. Epidemiologie de la sclerose en plaques en Bretagne. Presse Med 1983; 12: 995-999.

129. Lauer K, Firnhaber W, Reining R, et al. Epidemiological investigations into multiple sclerosis in Southern Hesse. I. Methodological problems and basic epidemiological characteristics. Acta Neurol Scand 1984; 70: 257-265.

130. Milonas I, Tsounis S, Logothetis I. Epidemiology of multiple sclerosis in northern Greece. Acta Neurol Scand 1990; 81: 43-47.

131. Yu YL, Woo E, Hawkins BR, et al. Multiple sclerosis amongst Chinese in Hong Kong. Brain 1989; 112: 1445-1467.

132. Palffy G. MS in Hungary, including the gipsic population. $/ m$ : Kuroiwa Y, Kurland LT, eds. Multiple Sclerosis. East and West. Kyushu: Kyushu University Press, 1982: 149-157.

133. Wadia NH, Bhatia K. Multiple sclerosis is prevalent in the Zoroastrians (Parsis) of India. Ann Neurol 1990: 28: 177-179.

134. Leibowitz U, Kahana E, Alter M. Multiple sclerosis in immigrant and native populations of Israel. The Lancet 1970: 1: 1323-1325.

135. Sironi L, Mamoli A, D Alessandro G, et al. Frequency of multiple sclerosis in Valle d'Aosta, 1971-1985. Neuroepidemiology 1991; 10: 66-69.

136. Kuroiwa Y, Shibasaki H, Ikeda M. Prevalence of multiple sclerosis and its north-south gradient in Japan. Neuroepidemiology 1983; 2: $62-69$

137. Kim SW, Kim SY. Multiple sclerosis in Busan, Korea. Clinical features and prevalence. In: Kuroiwa Y, Kurland LT, eds Multiple Sclerosis. East and West. Kyushu: Kyushu University Press, 1982: 57-69.

138. Park CS. Multiple sclerosis in Korea. Neurology 1966; 16: 919-926.

139. Al-Din ASN. Multiple sclerosis in Kuwait: clinical and epidemiological study. J Neurol Neurosurg Psychiatry 1986: 49: 928-931.

140. Radhakrishnan K, Ashok PP, Sridharan R, et al. Prevalence and pattern of multiple sclerosis in Benghazi. North-Eastern Libya. J Neurol Sci 1985; 70: 39-46.

141. Tan C-T. Multiple sclerosis in Malaysia. Arch Neurol 1988; 45: 624-627.

142. Alter M, Olivares L. Multiple sclerosis in Mexico. Arch Neurol 1970; 23: 451-459.

143. Skegg DCG, Corwin PA, Craven RS. et al. Occurrence of multiple sclerosis in the north and south of New Zealand. J Neurol Neurosurg Psychiatry 1987: 50: 134-139.

144. Yaquib BA, Daif AK. Multiple sclerosis in Saudi Arabia. Neurology 1988; 38: 621-623.

145. Geogi F, Hall P, Muller HR. Zur Problematik der multiplen Sklerose. Karger, Basel New York, 1961. (Cited by Bauer ${ }^{13}$ ).

146. Bartschi-Rochaix W. MS in Switzerland Canton Wallis. In: Bauer HJ, Poser S, Ritter G, eds. Progress in Multiple Sclerosis Research. New York: Springer, 1980: 535-538.

147. Hung T-P. Multiple sclerosis in Taiwan: a reappraisal. In: Kuroiwa Y, Kurland, LT, eds. Multiple Sclerosis. East and West. Kyushu: Kyushu University Press, 1982: 83-96.

148. Ben Hamida M. La sclerose en plaques en Tunisie: etude clinique de 100 observations. Rev Neurol (Paris) 1977: 33: 109-117.

149. Williams ES, McKeran RO. Prevalence of multiple sclerosis in a south London borough. Br Med J 1986; 293: 237-239.

150. Swingler RJ, Compston DAS. The prevalence of multiple sclerosis in South East Wales. J Neurol Neurosurg Psychiatry 1988; 51: 1520-1524.

151. Phadke JG, Downie AW. Epidemiology of multiple sclerosis in the north-east (Grampian Region) of Scotland - an update. J Epidemiol Comm Health 1987; 41: 5-13.

152. Cook SD, MacDonald J, Tapp W, et al. Multiple sclerosis in the Shetland Islands: an update. Acta Neurol Scand 1988; 77: 148151.

153. Cook SD, Cromarty JI. Tapp W. et al. Declining incidence of multiple sclerosis in the Orkney Islands. Neurology 1985: 35: 545551.

154. Dean G, Goodall J, Downic A. The prevalence of multiple sclerosis in the Outer Hebrides compared with north-east Scotland and the Orkney and Shetland Islands. J Epidemiol Comm Health 1981: 35: 110-113. 
155. Alter M, Okihiro M, Rowley W, et al. Multiple sclerosis among orientals and caucasians in Hawaii. Neurology 1971; 21: 122130.

156. Enstrom JE, Operskalski EA. Multiple sclerosis among Spanishsurnamed Californians. Neurology 1978; 28: 434-438

157. Visscher BR, Detels R, Coulson AH et al. Latitude, migration and the prevalence of multiple sclerosis. Am J Epidemiol 1977; 106: 470-475.

158. Sepcic J, Antonelli L, Materljan E, et al. Multiple sclerosis cluster in Gorski Kotar, Croatia, Yugoslavia. In: Battaglia MA, ed. Multiple Sclerosis Research. Amsterdam: Elsevier Science Pub, 1989: 165-169.
159. Rosati G, Aiello I, Pirastru MI. et al. Sardinia: a high-risk area for multiple sclerosis: a prevalence and incidence study in the district of Alghero. Ann Neurol 1987; 21: 190-194.

160. Salerni E, D'Aurizio CD, Andrea FD, et al. A prevalence study of multiple sclerosis in L'Aquila, central Italy. Clin Neurol Neurosurg 1988; 90: 112-116.

161. Granieri E, Tola R, Paolino E, et al. The frequency of multiple sclerosis in Italy: a descriptive study in Ferrara. Ann Neurol 1985; 17: 80-84. 